Jorge Terrados*, Arnaldo Marín and David Celdrán

\title{
Use of Posidonia oceanica seedlings from beach- cast fruits for seagrass planting
}

\begin{abstract}
Posidonia oceanica seedlings produced from beach-cast fruits were planted in an area where this Mediterranean seagrass was lost as a consequence of fishfarming. The effects of substratum type (dead matte vs. meadow) and planting level (above vs. below bottom surface) on seedling survivorship and leaf development were evaluated after 3 years. Seedling capacity to resist uprooting was also tested by comparing survivorship and leaf development after 2 years in seedlings firmly anchored in dead matte by artificial means (mesh-pot) with those planted without any anchoring other than their roots. Survivorship in dead matte was $44 \%$ after 3 years and was not affected by planting level. Seedling planting inside the meadow led to complete mortality after 3 years. Seedlings planted below the bottom surface branched during the second year and 50\% had produced from one to five additional shoots after 3 years. After 2 years, survivorship and leaf development of seedlings planted with mesh-pot anchoring was similar to that of seedlings planted without anchoring. Current environmental conditions in the impacted area allow $P$. oceanica seedlings to survive, but natural recovery might be limited by propagule availability. Planting of seedlings in dead matte without anchoring does not affect survivorship and leaf development and might be a feasible technique for restoration of $P$. oceanica meadows.
\end{abstract}

Keywords: leaf development; Posidonia oceanica; restoration; seedlings; survivorship.

*Corresponding author: Jorge Terrados, IMEDEA (CSIC-UIB) Instituto Mediterráneo de Estudios Avanzados, C/ Miquel Marqués 21, 07190 Esporles, Mallorca, Spain,

e-mail: terrados@imedea.uib-csic.es

Arnaldo Marín and David Celdrán: Facultad de Biología, Departamento de Ecología e Hidrología, Universidad de Murcia, Campus Universitario de Espinardo, 30100 Murcia, Spain

\section{Introduction}

Seagrass meadows are important components of shallow coastal ecosystems for their contribution to biodiversity, biological productivity, nutrient cycling, carbon burial and sediment stabilisation (Hemminga and Duarte 2000). In the last century, human populations in coastal zones have been rapidly increasing. This has increased anthropogenic impacts on seagrass ecosystems, in turn leading to a worldwide decline of seagrasses (Orth et al. 2006a, Waycott et al. 2009). Seagrass declines have stimulated interest in seagrass restoration research, and several approaches have been used (Fonseca et al. 1998, Treat and Lewis 2006, Paling et al. 2009) because adaptation to local conditions and to the features of the seagrass species to be planted is required. A record of seagrass presence in the past, knowledge about what caused seagrass loss and cessation of the activity that caused it are the first requirements that a restoration site should meet (Fonseca et al. 1998, van Katwijk et al. 2009). Verification that current environmental conditions allow seagrass presence is the next requirement and may be achieved through an assessment of critical environmental factors (i.e., light availability, disturbance by waves or bioturbators) and test-transplants (Short et al. 2002).

Posidonia oceanica is endemic to the Mediterranean Sea, where it forms extensive meadows down to depths of $45 \mathrm{~m}$ (Procaccini et al. 2003), meadows that have lost between $5 \%$ and $20 \%$ of their surface area during the last century (Boudouresque et al. 2009). Posidonia oceanica is a slow-growing seagrass species (Marbà and Duarte 1998) with low sexual reproduction (Díaz-Almela et al. 2006), and these features make recovery from disturbance slow (González-Correa et al. 2005, Kendrick et al. 2005). The consensus is that $P$. oceanica losses are irreversible within human time scales (Boudouresque et al. 2009), but this has not prevented exploration of the ways in which $P$. oceanica plantings might facilitate meadow recovery.

The first attempts to plant $P$. oceanica date back to the early 1970s, using fragments of adult plants (Boudouresque 2002). Experimental research was performed in the late 1980s to evaluate the use of vegetative fragments as planting units. Orthotropic rhizomes showed the highest survivorship when planted in autumn (Meinesz et al. 1992) and at depths shallower than their origin (Molenaar and Meinesz 1992). Plagiotropic rhizomes with one apical and two lateral shoots performed better than orthotropic 
rhizomes with one or two shoots (Molenaar et al. 1993). Plagiotropic rhizomes closely planted (5-10 cm apart) in spring in dead matte and in fine sand colonised by another seagrass (Cymodocea nodosa) showed more than 80\% survivorship after 3 years (Molenaar and Meinesz 1995). The use of vegetative fragments of $P$. oceanica as planting units is supported by evidence that drifting vegetative fragments can re-establish and colonise new areas (Di Carlo et al. 2005, Díaz-Almela et al. 2008). Indeed, stormgenerated fragments of $P$. oceanica have been successfully used as planting units (Augier et al. 1996), and they maintain their capacity to grow and re-establish when transferred to sea, even after 3 years of storage in outdoor tanks (Balestri et al. 2011).

Low and variable flowering (Díaz-Almela et al. 2006) and high rates of fruit abortion and predation (Balestri and Cinelli 2003) mean that the availability of $P$. oceanica seeds and seedlings is very low and unpredictable, and their use as planting units has been sporadic (Meinesz et al. 1993, Balestri et al. 1998). Mature seeds of $P$. oceanica found as drift material on beaches are, however, a potential source of seedlings for planting (Belzunce et al. 2005, 2008). For example, P. oceanica seedlings from shoreline drift that were planted in dead matte (the mixture of rhizomes, roots and sediment that this species forms) had a 70\% survivorship after 3 years, whereas none of those planted in gravel survived (Balestri et al. 1998).

Research on the conditions and processes that govern the establishment, survival and growth of seagrass planting units, whether vegetative fragments, seeds or seedlings, is essential for understanding natural colonisation and recovery from disturbance of seagrass meadows and to guide their possible restoration. This study reports the results of two test-transplants using $P$. oceanica seedlings in an area affected by fish-farming. Our first goal was to test if current environmental conditions in the impacted area allow the survival of $P$. oceanica seedlings. Lack of seedling recruitment suggests that either the impacted area is not suitable for seagrass growth or that some barrier to seagrass colonisation exists. Survivorship and leaf development of seedlings planted in the impacted area were compared over 3 years with those of seedlings planted inside the adjacent meadow, where $P$. oceanica persisted throughout fish-farming activities and currently forms a meadow with almost $100 \%$ cover. The second goal was to test if seedlings planted in dead matte were able to resist uprooting. Survivorship and leaf development of seedlings firmly anchored in the substratum were compared over 2 years with those of seedlings planted without any anchoring device other than their roots.

\section{Materials and methods}

\section{Study site}

Hornillo Bay (Águilas, southeast Spain; N $37^{\circ} 24.61^{\prime}$, W $1^{\circ}$ $\left.33.45^{\prime}\right)$ is a small bay that once supported a continuous Posidonia oceanica (L.) Delile meadow between depths of $5 \mathrm{~m}$ and $25 \mathrm{~m}$. Fish farming started in 1989 and, 10 years later, 11 ha of the meadow had been lost ( $28 \%$ of meadow extent in the bay), whereas another 10 ha were degraded (Ruiz et al. 2001). The fish farm was dismantled between 2000 and 2003, but no recruitment of P. oceanica seedlings has been observed in the impacted area, where the substratum is dead matte. Extensive meadows of $P$. oceanica are still present both inside and outside the bay (Figure 1).

\section{Culture of $P$. oceanica seedlings}

Similar to other species of the genus Posidonia, P. oceanica has non-dormant seeds and positively buoyant fruits, being dispersed by water currents after release from the parent plant (Kuo and den Hartog 2006). The fruit has a spongy pericarp that dehisces longitudinally to release a single, sinking seed. Mature seeds show well-developed leaf and root primordia, vascular tissue and high starch content (Belzunce et al. 2005). Seed-bearing fruits can be found on beaches, sometimes in large amounts (Balestri et al. 2008), and they are a source of viable seeds (Belzunce et al. 2008). The culture of beach-cast seeds of $P$. oceanica in aquaria to produce seedlings is a straightforward procedure that has been repeatedly demonstrated (Caye and Meinesz 1989, Buia and Mazzella 1991, Meinesz et al. 1993, Bedini 1997, Balestri et al. 1998, Belzunce et al.2008). Carbon and nutrient reserves contained in the seed are thought to be sufficient to allow the vegetative development of seedlings for 6-8 months after germination (Belzunce et al. 2008, Balestri et al. 2009).

\section{Planting of $P$. oceanica seedlings}

Two experiments were performed: one started in July 2008 (Experiment 1) and the other in July 2009 (Experiment 2). Seedlings were cultured in the laboratory from fruits collected on nearby beaches during May-June of 2008 and 2009. Briefly, fruits were opened carefully, the seed extracted and each one placed inside a plastic mesh-pot filled with fibreglass wool (Figure 2A). We used the meshpots to minimise damage to seedlings, especially the roots, 

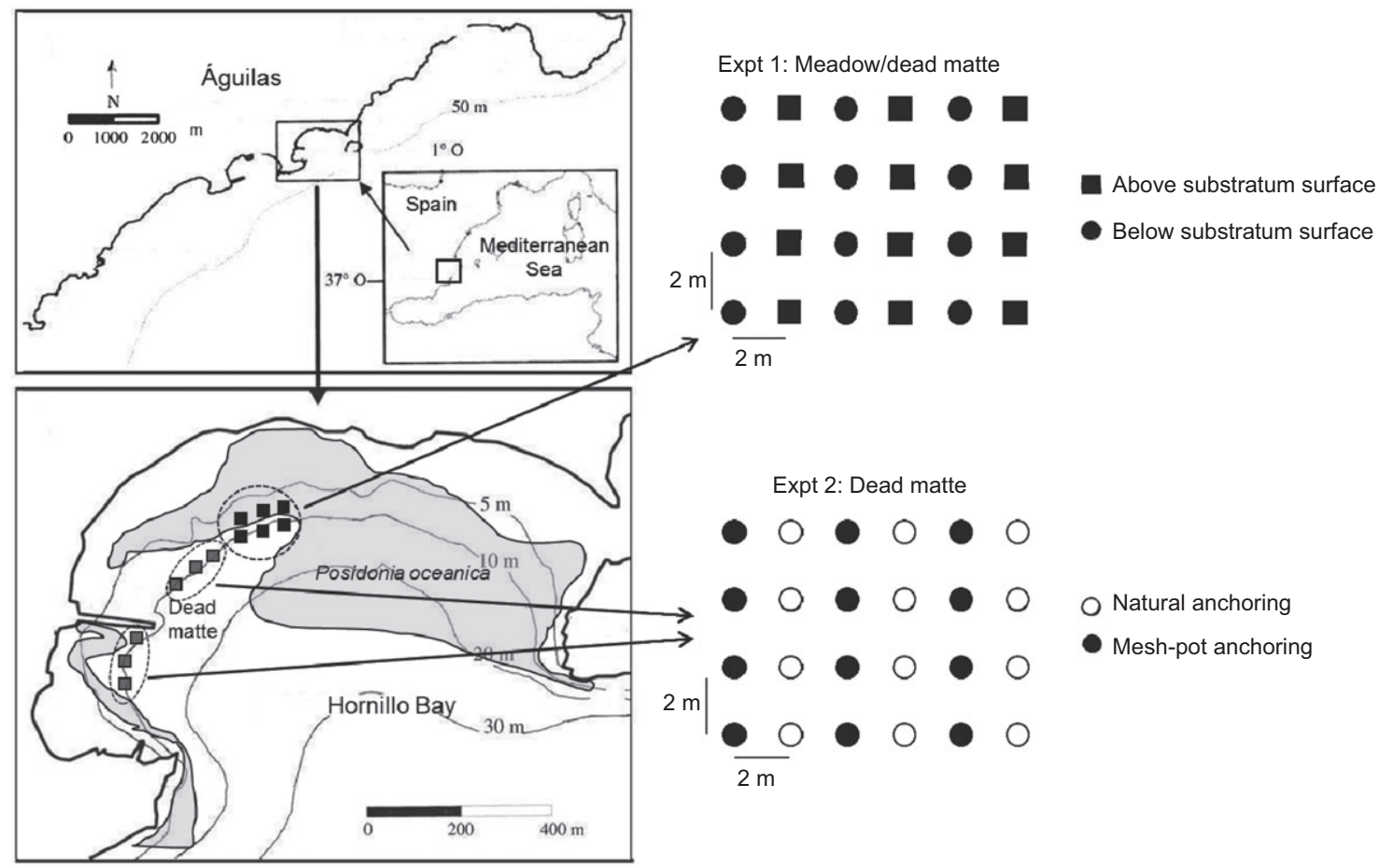

Figure 1 Posidonia oceanica.

Location of the study site and layout of seedlings and treatment levels in plots for Experiment 1 (substratum type, planting level) and Experiment 2 (anchoring). Black and grey squares represent Experiment 1 and Experiment 2 plots, respectively. The distance between plots in the map is not to scale.

during handling and planting, and to facilitate anchoring in the field. Fibreglass wool is an inert substratum that allows the development of seedling roots while protecting them from mechanical damage. The mesh-pots were placed in a closed, recirculating system of aquaria filled with seawater (salinity, 38) at a temperature of $21^{\circ} \mathrm{C}$ and average photosynthetic photon flux density at the surface of seedling leaves $>100 \mu \mathrm{mol} \mathrm{m} \mathrm{m}^{-2} \mathrm{~s}^{-1}$ provided by $500-\mathrm{W}$ halogen lamps, with a 12:12 $\mathrm{h}$ light:dark photoperiod. Germination proceeded under these laboratory culture

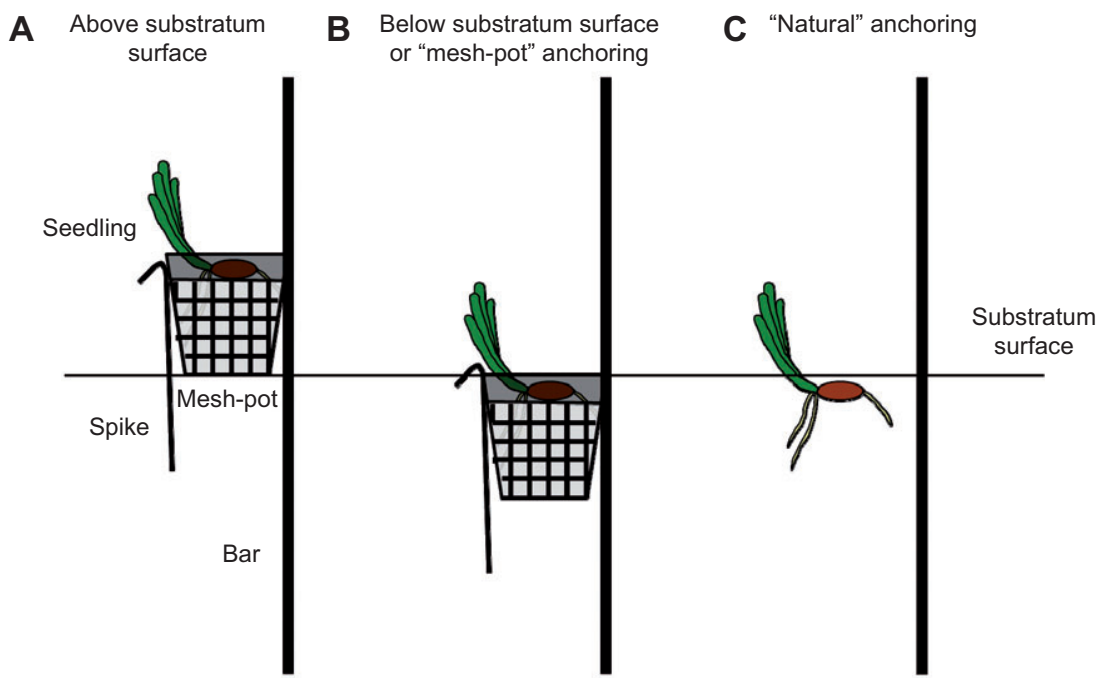

Figure 2 Posidonia oceanica.

Drawings of anchoring systems and planting levels used in Experiment 1, substratum type and planting level (A, B), and Experiment 2, anchoring (B, C). Mesh size of mesh-pots is $1 \mathrm{~cm}^{2}$. 
conditions, and, after 8-12 weeks, the seedlings used for experimental planting had 7-8 leaves and 1-3 roots.

\section{Experiment 1: substratum type and planting level}

Seedlings were planted following a two-way factorial design with two fixed factors, substratum type (dead matte vs. meadow) and planting level (above vs. below substratum surface) (Figures 1 and 2A, B). Contrasting planting levels were chosen to evaluate if the extent of contact with sediment affected seedling performance because sediment loading with organic matter from fish faeces and uneaten fish food is considered to be the main driver of aquaculture-related seagrass losses (DíazAlmela et al. 2009). Posidonia oceanica forms extensive meadows in sand, but its presence in rocky substrata is also common (Procaccini et al. 2003) and indicates that seedlings are able to establish themselves in limited amounts of sediment. Seedlings were planted in an established meadow to assess the overall effect of seedling manipulation during planting, and it was expected that they would survive and develop because environmental conditions in the meadow allow the growth of adult plants.

Three experimental areas were selected along the boundary between the impacted area (dead matte) and the P. oceanica meadow. A "dead matte" plot and a "meadow" plot were established on either side of the boundary (Figure 1). The distance between consecutive areas was $25 \mathrm{~m}$, and the water depth changed from $8.3 \mathrm{~m}$ to $12.1 \mathrm{~m}$. Each plot was made up of four parallel lines of six seedlings: the distance between seedlings in a line was $2 \mathrm{~m}$, as was the distance between lines (Figure 1). Similarsized seedlings were selected, and a sub-sample of them $(n=43)$ was measured (number of leaves, width and length of each leaf) before planting to provide an estimate of the initial leaf development of the seedlings. Seedlings were then assigned haphazardly to the three areas. A total of 24 seedlings were planted in each plot, and the planting level was assigned alternately to the seedlings so that there were 12 seedlings per plot and planting level. Each mesh-pot was anchored to the substratum by a $60-\mathrm{cm}$ corrugated iron bar and a $30-\mathrm{cm}$ galvanized iron spike fixed on opposite sides. Mesh-pots were placed either over the substratum surface or buried to the brim in the sediment (Figures 1 and 2A, B). All seedlings were planted on July 28-29, 2008.

The plots were monitored after 1 (July 2009), 2 (July 2010) and 3 years (July 2011) to assess seedling survivorship and leaf development. Survivorship was expressed as the percentage of seedlings surviving relative to the initial number of seedlings planted in each plot. The numbers of shoots and leaves of each seedling were counted, and the length and width of each leaf of each seedling were measured at each monitoring date. The presence of two shoots in a seedling was considered a branching event, because seedlings at planting time had one shoot only. The percentage of seedlings that had branched by each monitoring date was calculated for each plot. Leaf development was also described in terms of the number of shoots and leaves per seedling and leaf surface area $\left(\mathrm{cm}^{2}\right)$ per seedling. The percentages of seedling survivorship and branched seedlings were calculated for each plot. Average values per plot of the numbers of shoots and leaves per seedling and of leaf surface area $\left(\mathrm{cm}^{2}\right)$ per seedling were calculated and used in statistical analysis.

\section{Experiment 2: anchoring}

Seedlings were planted either firmly anchored in dead matte as in Experiment 1 or without any anchoring other than their roots, that is, "mesh-pot" vs. "natural" anchoring (Figures 1 and 2B, C). Six experimental plots were haphazardly selected in the impacted area at a water depth of $11 \mathrm{~m}$, and 24 seedlings were haphazardly assigned to each plot. Half of the seedlings were planted inside mesh-pots below the substratum surface (Figure 2B), whereas the other half were extracted from the mesh-pots, a small hole was dug in the dead matte and each seedling was carefully planted by hand, leaving the seed coat just below the surface of the substratum (Figure $2 \mathrm{C}$ ). A labelled $60-\mathrm{cm}$ corrugated iron bar was inserted near each of these seedlings to mark their position in the plots. As for Experiment 1 , each plot was made up of four parallel lines of six seedlings, the distance between consecutive seedlings in a line was $2 \mathrm{~m}$, the distance between lines was $2 \mathrm{~m}$ and the factor levels ("mesh-pot" vs. "natural" anchoring) were alternated along the lines (Figure 1).

The numbers of shoots and leaves of each seedling were counted in situ, and the length and width of each leaf of each seedling were measured in situ to quantify leaf development at planting time (July 15-17, 2009), and these measurements were repeated in the surviving seedlings after 1 (July 2010) and 2 years (July 2011). The percentages of seedling survivorship and branched seedlings were calculated for each plot. Average values per plot of the numbers of shoots and leaves per seedling and of leaf surface area $\left(\mathrm{cm}^{2}\right)$ per seedling were calculated and used in statistical analysis. 


\section{Data analysis}

Two-way factorial analysis of covariance (ANCOVA) was used to evaluate the significance of the effects of substratum type, planting level and the interaction of both factors on seedling survivorship and leaf development 1 year after planting (July 2009) in Experiment 1. The depth of plot was included as a covariate because it changed from $8.3 \mathrm{~m}$ to $12.1 \mathrm{~m}$. Homogeneity of within-group regression slopes was confirmed prior to performing ANCOVA and Cochran's C-tests indicated that group variances were homogeneous.

Most of the seedlings planted in "meadow" plots had died 2 years after planting, and none were left after 3 years (Figure 3). Hence, repeated-measures analysis of variance (ANOVA) was used to evaluate the effect of planting level on seedling survivorship and leaf development only in “dead matte" plots from July 2009 to July 2011. Mauchley tests indicated that the assumption of sphericity of the variance-covariance matrix was not violated. Depth was not considered a covariate in this analysis because all planting levels were at the same depths and previous ANCOVA indicated that depth had no significant effect.

Survivorship and leaf development of seedlings with mesh-pots and natural anchoring were compared from July 2009 to July 2011 using repeated-measures ANOVA. The sphericity assumption was checked using the Mauchley test and, if violated, the Greenhouse-Geisser and Huynh-Feldt adjusted probabilities are provided.

Data analysis was performed using STATISTICA v. 7.1 software (StatSoft, Inc. 2005). The significance level was set to 0.05 for all analyses.

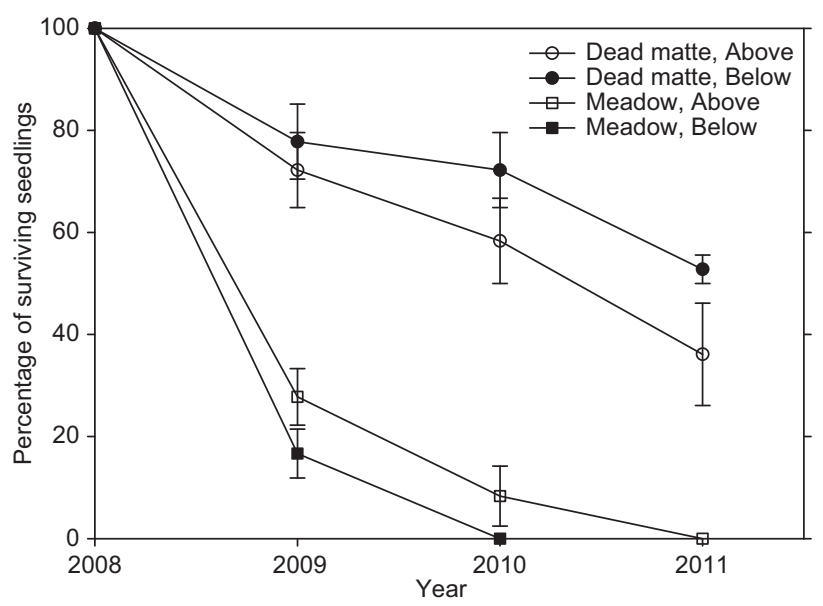

Figure 3 Posidonia oceanica.

Experiment 1: substratum type and planting level. Survivorship of seedlings (as a percentage of the initial number of seedlings planted) planted in Hornillo Bay (Águilas, southeast Spain) from July 2008 to July 2011. Error bars indicate \pm SE $(n=3)$.

\section{Results}

\section{Experiment 1: substratum type and planting level}

Seedling survivorship in July 2009 was higher in dead matte plots $(75 \% \pm 5 \%$, mean \pm SE) than in meadow plots $(22 \% \pm 4 \%)$ but was not affected by planting level (Figure 3, Table 1). Of 72 seedlings planted in meadow plots, 69 were dead in July 2010, and none were left in July 2011. However, seedling survivorship in dead matte plots was $65 \% \pm 6 \%$ in July 2010 and decreased to $44 \% \pm 6 \%$ in July 2011 . Planting level did not affect seedling survivorship in dead matte plots over the 3 years of the experiment (Table 2).

Seedlings had one shoot at planting time, and none of them had branched after 1 year (Figure 4A). Some seedlings that had been planted in dead matte below the substratum surface branched during the second and third years (Figure 4A), and 50\% of the surviving seedlings had produced from one to five additional shoots by July 2011. As a result, the average number of shoots per seedling planted in dead matte below the substratum surface increased from one shoot in July 2008 to $2.2 \pm 0.2$ shoots in July 2011 (Figure 4B).

At planting time (July 2008), seedlings had, on average, $8.2 \pm 0.3$ leaves with a total surface area of $17.9 \pm 0.8 \mathrm{~cm}^{2}$ (Figure 4C and D). The number of leaves in seedlings planted in meadow plots declined to $3.3 \pm 0.3$ in July 2009, whereas seedlings planted in dead matte plots had almost twice as many ( $5.9 \pm 0.3$ leaves per seedling; Table 1). The leaf number in seedlings planted in dead matte below the substratum surface had increased to $10.8 \pm 1.6$ by July 2011, whereas, in those planted above the substratum surface, it was $4.2 \pm 0.5$ (Figure 4C, Table 2: the yearxplanting level interaction was significant). The average leaf surface area of seedlings planted in dead matte below the substratum surface increased to $106.1 \pm 31.5 \mathrm{~cm}^{2}$ in July 2011, whereas that of the seedlings planted above the substratum surface was only $23.3 \pm 10.1$ $\mathrm{cm}^{2}$ (Figure 4D, Table 2: the year $\times$ planting level interaction was also significant).

\section{Experiment 2: anchoring}

Two years after planting, survivorship was $37 \% \pm 7 \%$ and $26 \% \pm 8 \%$ for seedlings with mesh-pots and natural anchoring, respectively (Figure 5). The repeated-measures ANOVA indicated that seedling survivorship was not affected by the type of seedling anchoring (Table 3). 
Table 1 Posidonia oceanica. ANCOVA of the effect of "substratum type" and "planting level" on seedling survivorship and leaf development (Experiment 1) in July 2009, 1 year after planting.

\begin{tabular}{|c|c|c|c|c|c|}
\hline & Source of variation & d.f. & MS & $\mathbf{F}$ & p-Value \\
\hline \multirow{5}{*}{$\begin{array}{l}\text { Seedling } \\
\text { survivorship,\% }\end{array}$} & Substratum type (S) & 1 & 5900.70 & 53.24 & $<0.001$ \\
\hline & Planting level (L) & 1 & 23.10 & 0.21 & 0.66 \\
\hline & $S \times L$ & 1 & 208.42 & 1.88 & 0.21 \\
\hline & Depth (covariate) & 1 & 196.39 & 1.77 & 0.22 \\
\hline & Error & 7 & 110.82 & & \\
\hline \multirow{5}{*}{$\begin{array}{l}\text { Number of leaves } \\
\text { per seedling }\end{array}$} & Substratum type (S) & 1 & 14.46 & 58.43 & $<0.001$ \\
\hline & Planting level (L) & 1 & 0.28 & 1.15 & 0.32 \\
\hline & $S \times L$ & 1 & 1.34 & 5.42 & 0.05 \\
\hline & Depth (covariate) & 1 & 0.29 & 1.18 & 0.31 \\
\hline & Error & 7 & 0.25 & & \\
\hline \multirow{5}{*}{$\begin{array}{l}\text { Leaf surface area }\left(\mathrm{cm}^{2}\right) \\
\text { per seedling }\end{array}$} & Substratum type (S) & 1 & 108.41 & 0.68 & 0.44 \\
\hline & Planting level (L) & 1 & 42.69 & 0.27 & 0.62 \\
\hline & $\mathrm{S} \times \mathrm{L}$ & 1 & 177.18 & 1.12 & 0.32 \\
\hline & Depth (covariate) & 1 & 81.18 & 0.51 & 0.50 \\
\hline & Error & 7 & 158.76 & & \\
\hline
\end{tabular}

Significant results are indicated in bold.

Some seedlings branched during the first year after planting, and $51 \%$ of the surviving seedlings had produced from one to three additional shoots after 2 years (Figure 6A). The number of shoots and the leaf surface area of the seedlings increased from July 2009 to July 2011, but these increases were not affected by the type of seedling anchoring (Figure 6B and D, Table 3). The number of leaves per seedling did not change during the experiment (Figure 6C, Table 3).

\section{Discussion}

Our results suggest that current environmental conditions in the fish-farm-impacted area do not prevent the survival of Posidonia oceanica seedlings because almost half of them (44\%) were able to survive for 3 years after planting. Survivorship of naturally recruited seedlings has been estimated to be $46 \%$ in rocky substratum after 2 years and $67 \%-70 \%$ in dead matte (Balestri

Table 2 Posidonia oceanica. Repeated-measures ANOVA of the effect of "planting level" on survivorship and leaf development of seedlings planted in "dead matte" plots (Experiment 1) from July 2009 to July 2011.

\begin{tabular}{|c|c|c|c|c|c|}
\hline & Source of variation & d.f. & MS & $\mathbf{F}$ & p-Value \\
\hline \multirow{5}{*}{$\begin{array}{l}\text { Seedling } \\
\text { survivorship,\% }\end{array}$} & Planting level (L) & 1 & 651.85 & 1.4319 & 0.30 \\
\hline & Error & 4 & 455.23 & & \\
\hline & Year (Y) & 2 & 1462.15 & 54.14 & $<0.001$ \\
\hline & $\mathrm{Y} \times \mathrm{L}$ & 2 & 50.07 & 1.85 & 0.22 \\
\hline & Error & 8 & 27.01 & & \\
\hline \multirow{5}{*}{$\begin{array}{l}\text { Number of leaves } \\
\text { per seedling }\end{array}$} & Planting level (L) & 1 & 57.55 & 14.49 & 0.02 \\
\hline & Error & 4 & 3.97 & & \\
\hline & Year (Y) & 2 & 5.79 & 6.17 & 0.02 \\
\hline & $Y \times L$ & 2 & 12.13 & 12.94 & 0.003 \\
\hline & Error & 8 & 0.94 & & \\
\hline \multirow{5}{*}{$\begin{array}{l}\text { Leaf surface area } \\
\left(\mathrm{cm}^{2}\right) \text { per seedling }\end{array}$} & Planting level (L) & 1 & 8041.32 & 4.20 & 0.11 \\
\hline & Error & 4 & 1916.41 & & \\
\hline & Year (Y) & 2 & 850.26 & 2.68 & 0.13 \\
\hline & $Y \times L$ & 2 & 2014.98 & 6.35 & 0.02 \\
\hline & Error & 8 & 317.10 & & \\
\hline
\end{tabular}

Significant results are indicated in bold. 

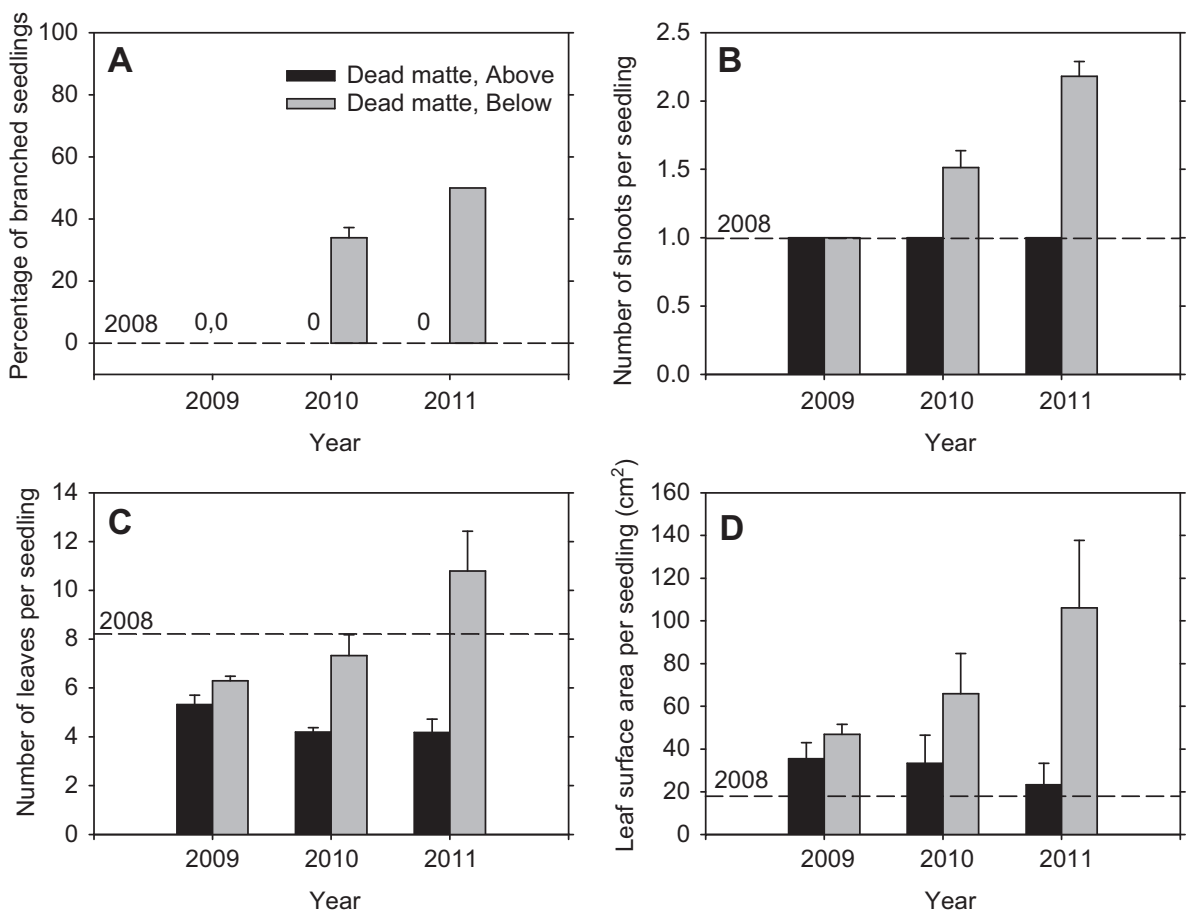

Figure 4 Posidonia oceanica.

Experiment 1: substratum type and planting level. Leaf development of seedlings planted in Hornillo Bay (Águilas, southeast Spain) from July 2008 to July 2011. (A) Percentage of seedlings that branched. (B) Number of shoots per seedling. (C) Number of leaves per seedling. (D) Leaf surface area per seedling. Error bars indicate $\pm S E(n=3)$. Horizontal broken line indicates values at planting time (July 2008). Results for meadow plots are not shown because most seedlings had died by 2010 .

et al. 1998, Piazzi et al. 1999) after 2 or 3 years; all of these estimates were at a depth of $10 \mathrm{~m}$, similar to our experiments. Seedlings planted below the substratum surface in the impacted area branched during the second year,

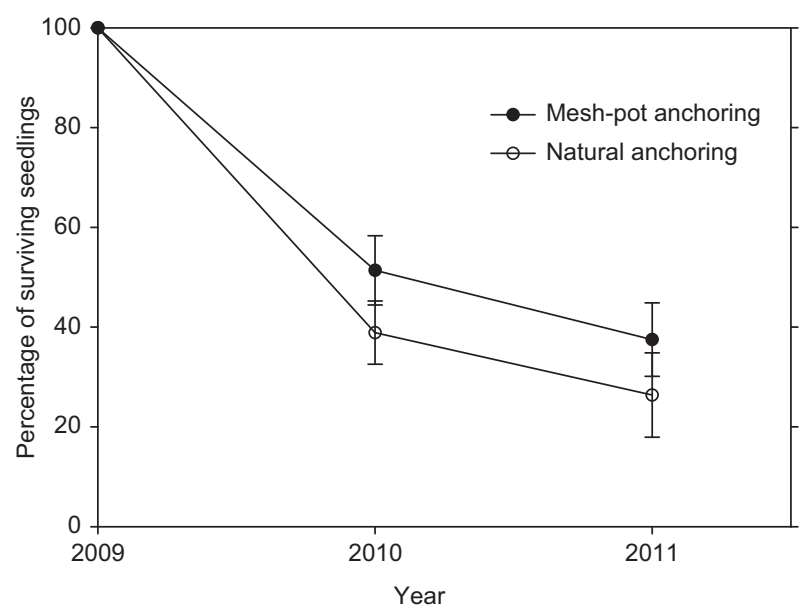

Figure 5 Posidonia oceanica.

Experiment 2: anchoring. Survivorship of seedlings (as a percentage of the initial number of seedlings planted) planted in Hornillo Bay (Águilas, southeast Spain) from July 2009 to July 2011. Error bars indicate $\pm \operatorname{SE}(\mathrm{n}=6)$. and $50 \%$ of them had produced at least one additional shoot after 3 years. Balestri et al. (1998) found that only $15 \%$ of seedlings naturally recruited in dead matte had produced a new shoot after 3 years. Hence, contact with sediment in the study site did not seem to be detrimental for seedling development, even though the organic matter content of sediment in the impacted area, from $2.2 \%$ to $3.5 \%$ of sediment dry weight (Domínguez et al. 2012), is higher than that of non-impacted areas nearby ( $<2 \%$ of sediment dry weight; Ruiz et al. 2001, Ramos et al. 2003). The absence of branching of seedlings planted above the substratum surface suggests that this planting level is not conducive to good vegetative development in the long-term.

Recruitment of $P$. oceanica seedlings occurs from May to August (Buia and Mazzella 1991) and seedlings can be found in rock, gravel and dead matte, but survivorship is highest in the latter (Balestri et al. 1998, Piazzi et al. 1999). The lower survivorship of seedlings established in dead matte at $2 \mathrm{~m}$ depth than at $10 \mathrm{~m}$ depth has been attributed to differences of water movement with depth (Piazzi et al. 1999). Hornillo Bay is exposed to prevailing winds and waves coming from east and southwest directions. However, seedlings planted with no anchoring had the 
Table 3 Posidonia oceanica. Repeated-measures ANOVA of the effect of seedling anchoring (Experiment 2) on survivorship and leaf development of seedlings planted in “dead matte” plots from July 2009 to July 2011.

\begin{tabular}{|c|c|c|c|c|c|}
\hline & Source of variation & d.f. & MS & $\mathbf{F}$ & p-Value \\
\hline \multirow{5}{*}{$\begin{array}{l}\text { Seedling } \\
\text { survivorship,\% }\end{array}$} & Anchoring $(A)$ & 1 & 836.23 & 1.37 & 0.27 \\
\hline & Error & 10 & 611.69 & & \\
\hline & Year (Y) & 1 & 1044.56 & 34.06 & $<0.001$ \\
\hline & $Y \times A$ & 1 & 2.89 & 0.09 & 0.76 \\
\hline & Error & 10 & 30.67 & & \\
\hline \multirow{5}{*}{$\begin{array}{l}\text { Number of leaves } \\
\text { per seedling }\end{array}$} & Anchoring $(A)$ & 1 & 1.54 & 0.46 & 0.52 \\
\hline & Error & 9 & 3.38 & & \\
\hline & Year (Y) & 2 & 1.65 & 0.96 & $0.40,0.37^{G-G}, 0.38^{H-F}$ \\
\hline & $Y \times A$ & 2 & 1.01 & 0.59 & $0.56,0.50^{\mathrm{G}-\mathrm{G}}, 0.53^{\mathrm{H}-\mathrm{F}}$ \\
\hline & Error & 18 & 1.71 & & \\
\hline \multirow{5}{*}{$\begin{array}{l}\text { Leaf surface area } \\
\left(\mathrm{cm}^{2}\right) \text { per seedling }\end{array}$} & Anchoring $(A)$ & 1 & 52.62 & 0.40 & 0.54 \\
\hline & Error & 9 & 132.20 & & \\
\hline & Year (Y) & 2 & 5286.15 & 70.21 & $<0.001$ \\
\hline & $Y \times A$ & 2 & 141.54 & 1.88 & 0.18 \\
\hline & Error & 18 & 75.30 & & \\
\hline
\end{tabular}

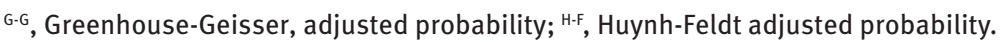

Significant results are indicated in bold.

same survivorship and leaf development as those firmly anchored using mesh-pots. This indicates that seedlings are able to withstand even the highest levels of hydrodynamic conditions that may occur in the impacted area during the year if seedling establishment is facilitated by planting. Drifting, unattached $P$. oceanica seedlings (natural recruits) were never observed in the experimental plots, and this suggests that seed supply in the impacted
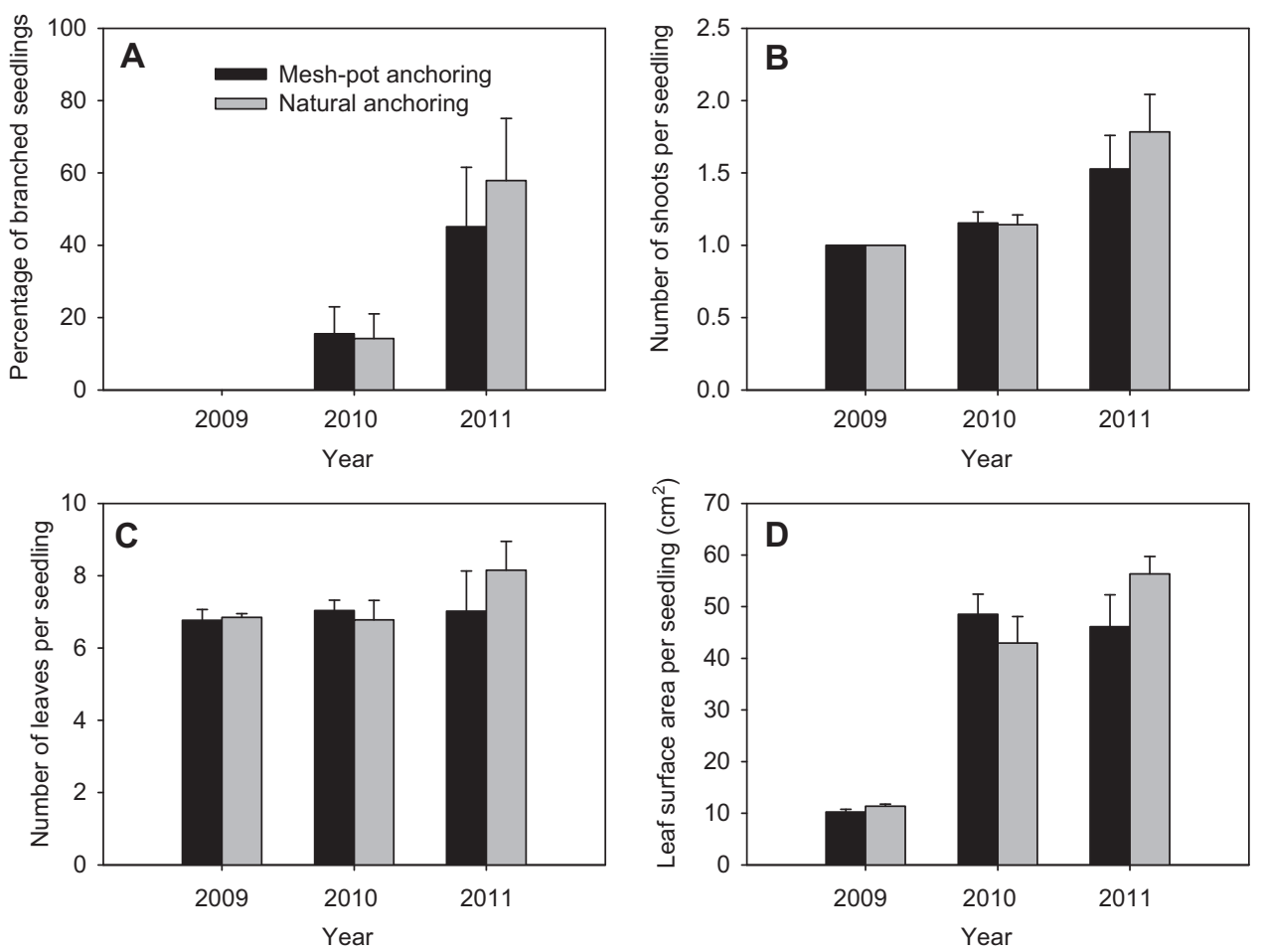

Figure 6 Posidonia oceanica.

Experiment 2: anchoring. Leaf development of seedlings planted in Hornillo Bay (Águilas, southeast Spain) from July 2009 to July 2011. (A) Percentage of seedlings that branched. (B) Number of shoots per seedling. (C) Number of leaves per seedling. (D) Leaf surface area per seedling. Error bars indicate $\pm S E(n=6)$. 
area might be very low. Discriminating among this and other possible causes limiting the natural recovery of the impacted area via sexual reproduction will require further experimental studies.

Seedlings planted inside the $P$. oceanica meadow were not able to survive, and most of them died after 2 years. We suggest that seedling development inside the $P$. oceanica meadow might be hindered by the shading imposed by the leaf canopy $\left(<60 \mu \mathrm{mol} \mathrm{m}^{-2} \mathrm{~s}^{-1}\right.$, a $95 \%$ reduction of the light reaching the top of the canopy; Domínguez et al. 2012), a light level that limits photosynthesis in this species (Alcoverro et al. 1998). Although this shading level might be considered maximal because $P$. oceanica leaf canopy achieves its maximum development in summer (Alcoverro et al. 1995), sustained low light might impose a negative carbon balance on the seedlings recruited in the meadow in the long-term. Shading has been also suggested as the process driving mortality. For example, the summer loss of seedlings recruited inside shallow (0.7 $\mathrm{m}$ depth) Zostera marina meadows in Limfjorden, Denmark (Olesen 1999). This hypothesis requires experimental testing.

Our results suggest that well-developed $P$. oceanica meadows are not suitable recruitment sites for seedlings if naturally-recruited seedlings perform in a similar way to those we planted. Discovering seedlings outside meadows led Balestri et al. (1998) to hypothesize that suitable recruitment sites might be separated from sites where adult plants occur, and we provide the first experimental evidence of the incapacity of transplanted $P$. oceanica seedlings to survive inside a well-developed meadow. Hence, sexual reproduction in $P$. oceanica would mainly contribute to the formation of new meadows in sites where the species is not present or to the recolonisation of defoliated, low-shoot density areas or meadow gaps. The positive buoyancy of $P$. oceanica fruits further suggests that sexual reproduction in this species facilitates plant dispersal and the formation of new meadows in locations far from the parent meadows. This is in line with evidence for other Posidonia species and other seagrasses with nondormant, buoyant fruits, such as Enhalus or Thalassia (reviewed by Orth et al. 2006b). The regular presence of $P$. oceanica meadows in rocky reefs (Procaccini et al. 2003) suggests that seedlings are also able to recruit in this type of substratum. Indeed, a high density ( 80 seedlings $\mathrm{m}^{-2}$ ) of 1-year-old seedlings established in shallow (2-3 $\mathrm{m}$ depth) rocks and sandy patches was reported in Corsica (Balestri and Lardicci 2008). Further studies are necessary to identify the mechanisms of establishment of P. oceanica seedlings in different types of substrata and the environmental conditions of the suitable recruitment sites.
Test-transplants to assess if environmental conditions allow seagrass presence is a main guideline in any restoration project (Fonseca et al. 1998, Short et al. 2002, van Katwijk et al. 2009). The use of seedlings for this purpose (Lewis 1987, Balestri et al. 1998, Kirkman 1999) and to evaluate different planting techniques (Marion and Orth 2010, Zarranz et al. 2010) has been satisfactory. In the case of $P$. oceanica, the only previous attempts to use seedlings in restoration were those of Balestri et al. (1998). Culture of beach-cast seeds of $P$. oceanica in aquaria to produce seedlings is a simple procedure (Caye and Meinesz 1989, Buia and Mazzella 1991, Meinesz et al. 1993, Bedini 1997, Balestri et al. 1998, Belzunce et al. 2008). These seedlings can be used to elucidate factors and processes affecting the early life of $P$. oceanica and evaluate planting techniques. This is a particularly useful approach considering that beach-cast $P$. oceanica fruits will eventually die. Thus, damage to donor meadows through seed removal or the extraction of plant fragments is avoided. The use of seeds or seedlings in seagrass restoration may have additional benefits because planting of vegetative fragments has been linked to low genetic diversity and poor performance of the planted stands (Williams 2001), and the genetic diversity of latter will be higher if seeds or seedlings are used.

The use of seedlings from beach-cast fruits appears a feasible alternative to restore damage caused to $P$. oceanica meadows. Our results confirm previous evidence that dead matte is an adequate substratum for the planting of $P$. oceanica seedlings (Balestri et al. 1998). The presence of dead matte indicates that environmental conditions in the past allowed P. oceanica growth and helps to achieve one of the main guidelines for choosing planting sites (Fonseca et al. 1998, van Katwijk et al. 2009). Dead matte allows planting of seedlings without anchoring, and this facilitates restoration work without compromising seedling survivorship. The low rhizome growth rate that characterises this species (Procaccini et al. 2003) means, however, that restoration success will be achieved only in the very long-term and only if the agents driving $P$. oceanica loss are eliminated. Low propagule availability is another constraint of $P$. oceanica planting. Given the uncertainties and constraints associated with restoration, regulation of anthropogenic activities that damage $P$. oceanica meadows is still the best strategy to preserve this valuable and fragile coastal ecosystem.

Acknowledgements: Funds were provided by research grant 116/SGTB/2007/1.3 of Ministerio de Medio Ambiente, 
Rural y Marino. D. Celdrán was supported by a FPU predoctoral scholarship awarded by Ministerio de Ciencia e Innovación. We are very grateful to Club Náutico de Águilas and CULMAREX fish-farm for granting the use of their facilities. We also thank M. Domínguez, A. Muñoz-Vera, E.
Infantes, F. Navarrete and J. Martínez for their help in field work.

Received September 3, 2012; accepted December 7, 2012; online first January 22, 2013

\section{References}

Alcoverro, T., C.M. Duarte and J. Romero. 1995. Annual growth dynamics of Posidonia oceanica: contribution of large-scale versus local factors to seasonality. Mar. Ecol. Prog. Ser. 120: 203-210.

Alcoverro, T., M. Manzanera and J. Romero. 1998. Seasonal and age-dependent variability of Posidonia oceanica (L.) Delile photosynthetic parameters. J. Exp. Mar. Biol. Ecol. 230: 1-13.

Augier, H., C. Eugene, J.M. Harmand-Desforges and A. Sougy. 1996. Posidonia oceanica re-implantation technology of the marine gardeners is now operational on a large scale. Ocean Coast. Manage. 30: 297-307.

Balestri, E. and F. Cinelli. 2003. Sexual reproductive success in Posidonia oceanica. Aquat. Bot. 75: 21-32.

Balestri, E. and C. Lardicci. 2008. First evidence of a massive recruitment event in Posidonia oceanica: spatial variation in first-year seedling abundance on a heterogeneous substrate. Estuar. Coast. Shelf Sci. 76: 634-641.

Balestri, E., L. Piazzi and F. Cinelli. 1998. Survival and growth of transplanted and natural seedlings of Posidonia oceanica (L.) Delile in a damaged coastal area. J. Exp. Mar. Biol. Ecol. 228: 209-225.

Balestri, E., F. Vallerini and C. Lardicci. 2008. A qualitative and quantitative assessment of the reproductive litter from Posidonia oceanica accumulated on a sand beach following a storm. Estuar. Coast. Shelf Sci. 66: 30-34.

Balestri, E., S. Gobert, G. Lepoint and C. Lardicci. 2009. Seed nutrient content and nutritional status of Posidonia oceanica seedlings in the northwestern Mediterranean Sea. Mar. Ecol. Prog. Ser. 388: 99-109.

Balestri, E., F. Vallerini and C. Lardicci. 2011. Storm-generated fragments of the seagrass Posidonia oceanica from beach wrack - A potential source of transplants for restoration. Biol. Conserv. 144: 1644-1654.

Bedini, R. 1997. Esperimenti di coltura di semi di Posidonia oceanica in aquario. Atti della Società Toscana di Scienze Naturali, Memorie, Serie B 104: 9-15.

Belzunce, M., R.M. Navarro and H.F. Rapoport. 2005. Seed and early plantlet structure of the Mediterranean seagrass Posidonia oceanica. Aquat. Bot. 82: 269-283.

Belzunce, M., R.M. Navarro and H.F. Rapoport. 2008. Posidonia oceanica seeds from drift origin: viability, germination and early plantlet development. Bot. Mar. 51: 1-9.

Boudouresque, C.F. 2002. La restauration des écosystèmes à phanérogames marines. In: (L. Drévès and M. Chaussepied, eds.) Restauration des écosystèmes côtiers. IFREMER Actes de colloques 29, Brest, November 8-9, 2000. IFREMER Publications, Issy-les-Moulineaux, France. pp. 65-85.

Boudouresque, C.F., G. Bernard, G. Pergent, A. Shili and M. Verlaque. 2009. Regression of Mediterranean seagrasses caused by natural processes and anthropogenic disturbances and stress: a critical review. Bot. Mar. 52: 395-418.

Buia, M.C. and L. Mazzella. 1991. Reproductive phenology of the Mediterranean seagrasses Posidonia oceanica (L.) Delile, Cymodocea nodosa (Ucria) Aschers., and Zostera noltii Hornem. Aquat. Bot. 40: 343-362.

Caye, G. and A. Meinesz. 1989. Cultures en milieu artificiel de Posidonia oceanica à partir de graines. In: (C.F. Boudouresque, A. Meinesz, E. Fresi and V. Gravez, eds.) International workshop on Posidonia beds 2. The second international workshop on Posidonia beds, Ischia, Italy, 7-11 October, 1985. G.I.S. Posidonie, Marseille. pp. 293-299.

Díaz-Almela, E., N. Marbà, E. Álvarez, E. Balestri, J.M. Ruiz-Fernández and C.M. Duarte. 2006. Patterns of seagrass (Posidonia oceanica) flowering in the western Mediterranean. Mar. Biol. 148: 723-742.

Díaz-Almela, E., N. Marbà, E. Álvarez, R. Santiago, R. Martínez and C.M. Duarte. 2008. Patch dynamics of the Mediterranean seagrass Posidonia oceanica: implications for recolonisation process. Aquat. Bot. 89: 397-403.

Díaz-Almela, E., N. Marbà, E. Álvarez, R. Santiago, M. Holmer, A. Grau, S. Mirto, R. Danovaro, A. Petrou, M. Argyrou, I. Karakassis and C.M. Duarte. 2009. Benthic input rates predict seagrass (Posidonia oceanica) fish farm-induced decline. Mar. Pollut. Bull. 56: 1332-1342.

Di Carlo, G., F. Badalamenti, A.C. Jensen, E.W. Koch and S. Riggio. 2005. Colonisation process of vegetative fragments of Posidonia oceanica (L.) Delile on rubble mounds. Mar. Biol. 147: 1261-1270.

Domínguez, M., D. Celdrán, A. Muñoz-Vera, E. Infantes, P. MartínezBaños, A. Marín and J. Terrados. 2012. Experimental evaluation of the restoration capacity of a fish-farm impacted area with Posidonia oceanica (L.) Delile seedlings. Restor. Ecol. 20: 180-187.

Fonseca, M.S., W.J. Kenworthy and G.W. Thayer. 1998. Guidelines for the conservation and restoration of seagrasses in the United States and adjacent waters. NOAA Coastal Ocean Program Decision Analysis Series No. 12. NOAA Coastal Ocean Office, Silver Spring, MD. pp. 222.

González-Correa, J.M., J.T. Bayle, J.L. Sánchez-Lizaso, C. Valle, P. Sánchez-Jerez and J.M. Ruiz. 2005. Recovery of deep Posidonia oceanica meadows degraded by trawling. J. Exp. Mar. Biol. Ecol. 320: 65-76.

Hemminga, M.E and C.M. Duarte. 2000. Seagrass ecology. Cambridge University Press, Cambridge. pp. 298.

Kendrick, G.A., N. Marbà and C.M. Duarte. 2005. Modelling formation of complex topography by the seagrass Posidonia oceanica. Estuar. Coast. Shelf Sci. 65: 717-725.

Kirkman, H. 1999. Pilot experiments on planting seedlings and small seagrass propagules in Western Australia. Mar. Pollut. Bull. 37: 460-467. 
Kuo, J. and C. den Hartog. 2006. Seagrass morphology, anatomy, and ultrastructure. In: (A.W.D. Larkum, R.J. Orth and C.M. Duarte, eds.) Seagrasses: biology, ecology and conservation. Springer, Dordrecht. pp. 51-87.

Lewis III, R.R. 1987. The restoration and creation of seagrass meadows in the Southern United States. In: (M.J. Durako, R.C. Phillips and R.R. Lewis III, eds.) Proceedings of the Symposium on Subtropical-Tropical Seagrasses of the Southeastern United States. Florida Marine Research Publications No. 42. Florida Department of Natural Resources, Bureau of Marine Research, St. Petersburg, FL. pp. 153-173.

Marbà, N. and C.M. Duarte. 1998. Rhizome elongation and seagrass clonal growth. Mar. Ecol. Prog. Ser. 174: 269-280.

Marion, S.R. and R.J. Orth. 2010. Factors influencing seedling establishment rates in Zostera marina and their implications for seagrass restoration. Restor. Ecol. 18: 549-559.

Meinesz, A., H. Molenaar, E. Bellone and F. Loquès. 1992. Vegetative reproduction in Posidonia oceanica I. Effects of rhizome length and transplantation season in orthotropic shoots. Mar. Ecol. 13: 163-174.

Meinesz, A., G. Caye, F. Loquès and H. Molenaar. 1993. Polymorphism and development of Posidonia oceanica transplanted from different parts of the Mediterranean into the National Park of Port-Cros. Bot. Mar. 36: 209-216.

Molenaar, H. and A. Meinesz. 1992. Vegetative reproduction in Posidonia oceanica II. Effects of depth changes on transplanted orthotropic shoots. Mar. Ecol. 13: 175-185.

Molenaar, H. and A. Meinesz. 1995. Vegetative reproduction in Posidonia oceanica: survival and development of transplanted cuttings according to different spacings, arrangements and substrates. Bot. Mar. 38: 313-322.

Molenaar, H., A. Meinesz and G. Caye. 1993. Vegetative reproduction in Posidonia oceanica. Survival and development in different morphological types of transplanted cuttings. Bot. Mar. 36: 481-488.

Olesen, B. 1999. Reproduction in Danish eelgrass (Zostera marina L.) stands: size-dependence and biomass partitioning. Aquat. Bot. 65: 209-219.

Orth, R.J., T.J.B. Carruthers, W.C. Dennison, C.M. Duarte, J.W. Fourqurean, K.L. Heck Jr., A.R. Hughes, G.A. Kendrick, W.J. Kenworthy, S. Olyarnik, F.T. Short, M. Waycott and S.L. Williams. 2006a. A global crisis for seagrass ecosystems. BioScience 56: 987-996.

Orth, R.J., M.C. Harwell and G.J. Inglis. 2006b. Ecology of seagrass seeds and seagrass dispersal processes. In: (A.W.D. Larkum, R.J. Orth and C.M. Duarte, eds.) Seagrasses: biology, ecology and conservation. Springer, Dordrecht. pp. 111-133.

Paling, E.I., M.S. Fonseca, M.M. van Katwijk and M. Van Keulen. 2009. Seagrass restoration. In: (G.M.E. Perillo, E. Wolanski,
D.R. Cahoon and M.M. Brinson, eds.) Coastal wetlands: an integrated ecosystem approach. Elsevier, Amsterdam. pp. 687-713.

Piazzi, L., S. Acunto and F. Cinelli. 1999. In situ survival and development of Posidonia oceanica (L.) Delile seedlings. Aquat. Bot. 63: 103-112.

Procaccini, G., M.C. Buia, M.C. Gambi, M. Pérez, G. Pergent, C. Pergent-Martini and J. Romero. 2003. The seagrasses of the western Mediterranean. In: (E.P. Green and F.T. Short, eds.) World atlas of seagrasses. UNEP World Conservation Monitoring Centre. University of California Press, Berkeley. pp. 48-58.

Ramos, M., A. Marín, R.V. Barberá, L.M. Guirao, A. César and J. Lloret. 2003. Evolución de las comunidades bentónicas de la bahía de El Hornillo (Águilas, Murcia) (sureste de España) finalizado el cultivo en jaulas flotantes de dorada Sparus auratus L., 1758 y lubina Dicentrarchus labrax (L., 1758). Bol. Inst. Esp. Oceanogr. 19: 379-389.

Ruiz, J.M., M. Pérez and J. Romero. 2001. Effects of fish farm loadings on seagrass (Posidonia oceanica) distribution, growth and photosynthesis. Mar. Pollut. Bull. 42: 749-760.

Short, F.T., R.C. Davis, B.S. Kopp, C.A. Short and D.M. Burdick. 2002. Site-selection model for optimal transplantation of eelgrass Zostera marina in the northeastern US. Mar. Ecol. Prog. Ser. 227: 253-267.

StatSoft, Inc. 2005. STATISTICA (data analysis software system), version 7.1. Tulsa, OK 74104, USA.

Treat, S.F. and R.R. Lewis III. 2006. Seagrass restoration: success, failure and the cost of both. Selected papers presented at a workshop, Mote Marine Laboratory, Sarasota, Florida, March 11-12, 2003. Lewis Environmental Services, Inc., Valrico, FL. pp. 175.

van Katwijk, M.M., A.R. Bos, V.N. de Jonge, L.S.A.M. Hanssen, D.C.R. Hermus and D.J. de Jong. 2009. Guidelines for seagrass restoration: importance of habitat selection and donor population, spreading of risks, and ecosystem engineering effects. Mar. Pollut. Bull. 58: 179-188.

Waycott, M., C.M. Duarte, T.J.B. Carruthers, R.J. Orth, W.C. Dennison, S. Olyarnik, A. Calladine, J.W. Fourqurean, K.L. Heck Jr, A.R. Hughes, G.A. Kendrick, W.J. Kenworthy, F.T. Short and S.L. Williams. 2009. Accelerating loss of seagrasses across the globe threatens coastal ecosystems. Proc. Nat. Acad. Sci. USA 106: 12377-12381.

Williams, S.L. 2001. Reduced genetic diversity in Z. marina transplantations affects both population growth and individual fitness. Ecol. Appl. 11: 1472-1488.

Zarranz, M.E., N. González-Henríquez, P. García-Jiménez and R.R. Robaina. 2010. Restoration of Cymodocea nodosa seagrass meadows through seed propagation: germination in vitro, seedling culture and field transplants. Bot. Mar. 53: 173-181. 